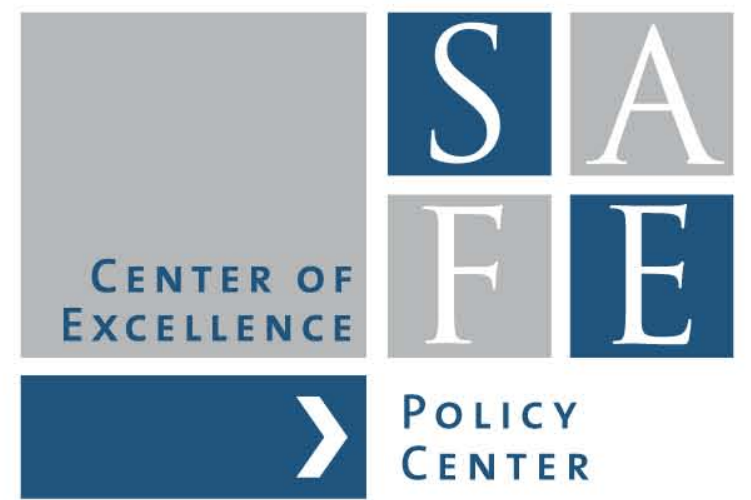

Prof. Dr. Katja Langenbucher

\title{
Legal aspects of gender balance on corporate boards in Germany
}

White Paper Series No. 2

Center of Excellence SAFE Sustainable Architecture for Finance in Europe A cooperation of the Center for Financial Studies and Goethe University Frankfurt 


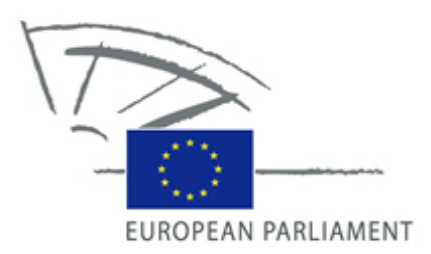

\author{
POLICY DEPARTMENT C: CITIZENS' RI GHTS AND \\ CONSTITUTI ONAL AFFAI RS
}

\author{
GENDER EQUALITY
}

\title{
Legal aspects of gender balance on corporate boards in Germany
}

\author{
NOTE
}

\begin{abstract}
The German corporate governance code includes a recommendation as to diversity on corporate boards. Two draft bills on gender quotas are currently under way in legislative proceedings. However, the ruling coalition rejects those, advocating a "flexible quota". Corporate law academic scholarship disapproves of gender quotas. This goes back to disapproval of the underlying policy and the fear of adverse consequences on corporate decision-making as well as the claim of incompatibility with European law and with German constitutional law.
\end{abstract}


This document was requested by Policy Department C of the European Parliament.

\section{AUTHOR(S)}

Prof. Dr. Katja Langenbucher

\section{RESPONSI BLE ADMI NI STRATOR}

Ms Claire Genta

Policy Department C: Citizens' Rights and Constitutional Affairs

European Parliament

B-1047 Brussels

E-mail: poldep-citizens@europarl.europa.eu

\section{NGUI STI C VERSI ONS}

Original: EN

\section{ABOUT THE EDITOR}

To contact the Policy Department or to subscribe to its monthly newsletter please write to: poldep-citizens@europarl.europa.eu

European Parliament, manuscript completed in March 2013.

(C) European Union, 2013.

This document is available on the Internet at:

http://www.europarl.europa.eu/studies

\section{SCLAI MER}

The opinions expressed in this document are the sole responsibility of the author and do not necessarily represent the official position of the European Parliament.

Reproduction and translation for non-commercial purposes are authorized, provided the source is acknowledged and the publisher is given prior notice and sent a copy. 


\section{Contents}

$\begin{array}{ll}\text { EXECUTI VE SUMMARY } & 26\end{array}$

1. TERMI NOLOGY AND LEGI SLATIVE CHALLENGES 27

1.1. Terminology: the gender "quota" 27

1.2. The elements of application $\quad 27$

$\begin{array}{ll}\text { 1.3. The sanctions } & 28\end{array}$

2. LEGI SLATI VE PROPOSALS I N GERMANY 30

2.1. The German corporate governance code 31

2.2. The "flexi-quota" proposal 31

2.3. The draft bill introduced by the social democratic party 32

2.4. The draft bill jointly introduced by the social democratic party and the green party $\quad 33$

3. ACADEMI C SCHOLARSHI P

3.1. The policies underlying a gender quota 35

3.2. Incompatibility with European law 35

3.3. I ncompatibility with German constitutional law 35

3.4. Lack of competence for the European legislator 36

3.5. Adverse consequences on corporate business 37

4. CONCLUDING REMARK 37

$\begin{array}{lr}\text { REFERENCES } & 38\end{array}$ 


\section{EXECUTI VE SUMMARY}

\section{Background}

This note has been requested by the European Parliament's Policy Department C "Constitutional Affairs and Citizens' Rights".

The underrepresentation of women on corporate boards has been a concern for legislators both at member states and at EU level. While there is widespread agreement as to the desirability of seeing more female directors - for reasons as diverse as enhancing shareholder value, reducing groupthink phenomena or improving social justice - no such agreement has been reached on the suitability of legislative measures. Suggestions on this issue range from legislative abstinence, over variations of "soft measures" to the introduction of "hard" gender quotas.

Germany has been seeing a lively political debate on this topic for two years. The Christiandemocratic government opposes "fix" quotas. Instead, it has been promoting a law obliging corporations to set their own "flexible" quota. However, no legislative procedure has yet been initiated by the government. The social-democratic party has introduced one farreaching legislative proposal. Lately, it joined forces with the green party in order to bring about a much milder proposal including however "fix" quotas.

\section{Aim}

The aim of the present study is to provide an overview on legislative proposals currently presented and on academic scholarship on the issue. Taking it from there, legal obstacles to the introduction of a "fix" quota under German law are discussed and the "soft" version of "flexible" quotas is being advocated. 


\section{TERMI NOLOGY AND LEGI SLATI VE CHALLENGES}

\section{KEY FI NDI NGS}

- For the purposes of this note, a gender "quota" is a figure detailing the proportion between men and women on a corporate board.

- Introducing legal rules on gender quotas requires carefully distinguishing the rule's elements of application from its sanctions.

- As to elements of application, a legislator introducing gender quotas will have to decide upon (i) which type of corporation and (ii) which type of board is to be addressed as well as (iii) who sets the quota and (iv) to what extent exceptions from the rule will be granted.

- As to sanctions, any legislation on gender quotas requires a decision upon transparency requirements and/or nullity or revocability of boards which do not comply with the quota requirement. The latter choice triggers a number of complex questions of corporate law. Further sanctions for boards violating a quota rule include fines, negative impact on pay or ineligibility for state bidding procedures.

Discussing gender quotas requires using precise terminology as well as a number of careful distinctions when comparing rules in different Member States or deciding upon legislative steps to take.

\subsection{Terminology: the gender "quota"}

For the purposes of this note, the term gender "quota" will be understood quite broadly to encompass any figure detailing the proportion between men and women on a corporate board. It is worth noting that gender quotas do not necessarily need a fix number (i. e. $40 \%$ ) or even a parameter set by the legislator (rather than by the corporation itself). Hence, I will speak of a country's law including a gender quota, whenever there are legal rules in place which require the competent body voting on the board's composition to specifically decide upon the number of women who should sit on that board. In the case of Germany, the competent body is the supervisory board when appointing the members of the management board (Vorstand). The shareholders general meeting is the competent body when voting for the supervisory board (Aufsichtsrat).

\subsection{The elements of application}

When we analyse legal rules it is helpful to distinguish the elements of applying the rule from the sanctions for not conforming to the rule. A rule on gender quotas will need to address a minimum of four elements of application (all of which are the object of debate in Germany).

- Taking into account the wide variety of business associations in Germany, ranging from private partnerships (Gesellschaft bürgerlichen Rechts) over commercial partnerships with full personal liability of at least one of the members (offene 
Handelsgesellschaft/Kommanditgesellschaft) to companies with limited liability (Gesellschaft mit beschränkter Haftung) and stock corporations (Aktiengesellschaft) a choice of the type of corporation addressed is required. Obliging a private partnership to decide upon a gender quota might be seen as a more drastic intervention in private law matters than requiring the same from a public stock corporation.

- Whenever a corporation has more than one type of board (dualistic system), a choice of the type of board addressed by a rule on gender quotas is required. It is a regular feature of companies with limited liability to separate owners (shareholders) from management. Managerial tasks may be executed by one board (monistic system) alternatively its tasks may be divided between a management and a supervisory board (dualistic system). German law allows for the dualistic system exclusively as far as stock corporations are concerned. While there is some feeble support for gender quotas as far as supervisory boards are concerned, both public opinion and academics seem to find it much harder to include management boards. Under German law, employee representatives are members of supervisory boards. Hence, the problem if and how employee representatives would need to be considered for a gender quota adds to complexity.

- We have mentioned earlier that it is not necessarily the legislator who sets a quota. While countries such as France and Norway have enacted laws featuring a legal quota, the choice of who sets a quota is still quite open in Germany. The socialdemocratic and the green party advocate a legislative quota, the governing Christiandemocratic party opts for each corporation to individually set the quota (see below 2.1.).

- Granting exceptions to a legal rule is often required in order to avoid undue consequences. Of course, the choice of exceptions to the rule is an important one. The more numerous the occasions which allow to disregard the rule, the less substance remains.

\subsection{The sanctions}

The efficiency of a legal rule to a large extent depends on the sanctions associated with it. As to gender quotas there are a number of general and some rather company-law specific sanctions. More general sanctions, as seen e. g. in France or Spain, include fines for boards not in conformity with a legal quota, negative impact on board member's pay or ineligibility for state bidding procedures. The German debate has focused on sanctions which more directly bear on company law.

- An obvious sanction for non-compliance with a gender quota is transparency. A transparency rule could require corporations to annually issue a statement on the gender quota of their boards. The policy underlying transparency rules of this type will be that non-compliance leads to reputational damage hence will be avoided.

- Significantly harsher are sanctions which entail implications for the proper composition of a board which is not in compliance with a quota. There are quite a number of possible strategies for a sanction of this type. All of them pose tricky questions under German law as far as supervisory board members are concerned. Those are not appointed, but elected by the shareholders. Hence, an election not in accordance with a quota would have to be nullified, should the legislator opt for implications for the proper composition of a board. 
- The law may altogether prevent a board not in compliance with a quota. The election (in the case of a shareholder vote on the board) or the appointment (in the case of the supervisory board appointing the management board) of such a board would be void or revocable. If a board composed in this non-compliant fashion nonetheless goes about its business, a number of complex questions of company law arise: Can actions of the non-compliant board bind the corporation? If not, will legitimate expectations of creditors be honoured? Will the body voting for/appointing the "wrong" board be liable for damages?

- Instead of declaring a non-compliant board null and void altogether, the legislator may opt for limiting the consequences to some of its members. Imagine a German supervisory board comprising 20 people, all male. Imagine further, German law introduced a legal gender quota of $25 \%$ on 1 st January 2014 , i. e. then requires 5 female members. The A-Corporation will hold elections of its supervisory board on 10th January 2014. Under German law, the supervisory board is not constituted in its entirety each year. Instead, each member of the supervisory board is typically elected for a bit less than five years. Members leaving the board earlier will make place for new members.1 Consequently, when the board in our example will be elected on 10th January 2014, there won't be 20 seats to fill, but less. If 5 seats will need to be filled on that day, there is a straightforward answer: We need 5 women. What happens if only 0 to 4 seats are empty? 2 Even if more than 5 seats will need to be filled, the answer is tricky: German law offers two ways of electing supervisory board members. Option (1) is the election "en bloc". A list is proposed to the shareholders, comprising the entirety of new members and the shareholders vote for the entire list. Let's assume in our example there are 7 new members on the list, but only 4 of them are women - will the entire election be void? Option (2) for electing supervisory board members is to individually vote for each member. Let us again assume there are 7 new members to be elected on 10th January 2014. We said 5 of those will need to be female. What happens if the shareholders assembly votes for candidates 1-2 (female), 3-5 (male), 6 (female), 7 (male)? Will the election of all male candidates be void or should only two elections be void? If the latter is the case, which ones of the male candidates need to go? Will all elections be void, since there are too few women?

\footnotetext{
${ }^{1}$ Section 102 German Stock Corporation Act (Aktiengesetz), cf. Langenbucher (2011a) § 5 recital 42.

${ }^{2}$ The answer obviously is: the legislator will need to provide for transitional arrangements.
} 


\section{LEGI SLATI VE PROPOSALS I N GERMANY}

\section{KEY FI NDI NGS}

- There is no legal quota for supervisory or management boards under German law.

- The German corporate governance code recommends "diversity" when appointing management board members and electing supervisory board members.

- The German government currently favours the family ministry's "flexi-quota" proposal. This proposal requires corporations to set their own quota, flexibly adjusted to their needs.

- The Social-democratic party has introduced an ambitious draft bill. The Socialdemocratic and the green party have jointly introduced another, less ambitious draft bill, hoping for a compromise and a quick legislative procedure.

The German government has seen extensive debate between the minister of labour (Ursula von der Leyen) and the minister of family (Kristina Schröder), the former opting for a fix quota of $30 \%$, the latter advocating a flexible quota to be introduced by the corporation itself (the so-called "flexi-quota"). Chancellor Merkel has backed the "flexi-quota" plan which includes a number of preliminary stages, leading up to legislative action at a later time only. The liberal-democratic party (coalition partner of the Christian-democratic party) opposes any quota.

\section{Figure 1: Women in supervisory and management boards in Germany}

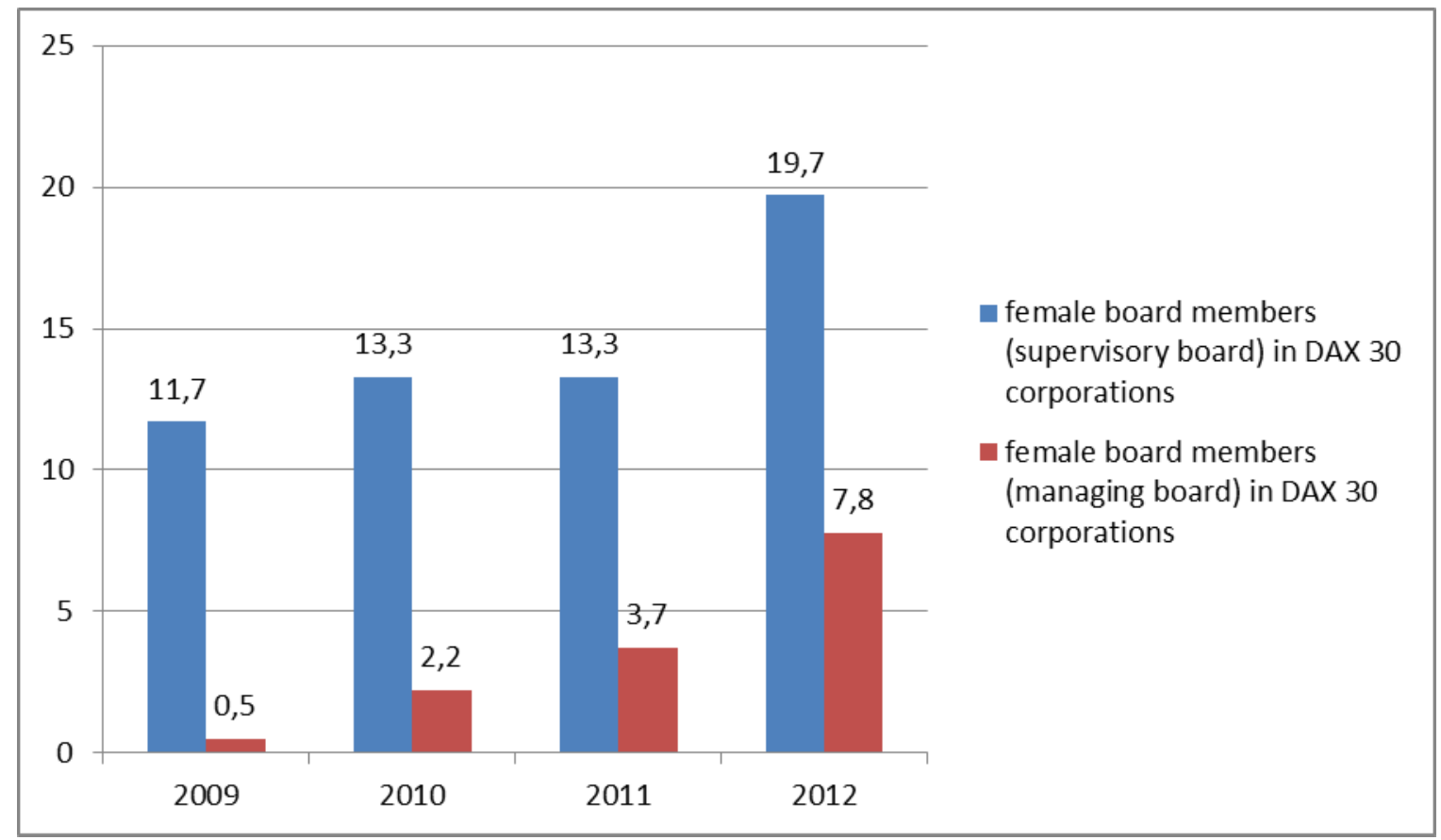

Source: Author and www.flexi-quote.de 


\subsection{The German corporate governance code}

The German corporate governance code sets out standards of good corporate governance. Listed stock corporations are required to report on their application of the code under a "comply-or-explain" structure provided for in section 161 German stock corporation act. The code comprises (1) rules which are binding under the German stock corporation act, (2) recommendations which corporations may deviate from when providing an explanation why they do and (3) mere suggestions which may be disregarded without reporting.

4.1.2 of the code recommends for the management board to have due regard for the benefits of diversity, notably gender, when hiring executive staff. 5.1 .2 of the code recommends the same for the supervisory board when appointing the members of the management board. 5.4.1 of the code recommends for the supervisory board to specify policies for its own composition including diversity. Special emphasis is placed on understanding the broader concept of "diversity" as focussed on gender.

The legal sanctions for not reporting on the application of the code at all or for falsely claiming to apply the code are a subject of hot debate under German law. ${ }^{1}$ Most authors agree that management and supervisory board members are liable for damages, yet losses which can be claimed are rare. In some cases, the false report may rule out formal approval of the board's conduct by the shareholder's assembly. Obviously, there are no sanctions for paying lip service only to the code provisions recommending diversity.

\subsection{The "flexi-quota" proposal}

The ministry of family has been advocating a law introducing a "flexi-quota". ${ }^{2}$ According to the minister's internet site www.flexi-quote.de, corporations will be required to individually set a gender quota. They will have to report on the quota chosen as well as on the point in time when the board plans to fully comply with the quota. Proponents of the flexi-quota point to the competitive advantage of catering to differences in female talent pools across industry sectors.

As to elements of application, the proposed quota covers companies which are listed and fall under the scope of mandatory employee representation. It applies to both, management and supervisory board.

With regard to sanctions, the proposal remains vague. The minimum sanction of transparency, i. e. reporting on the quota and its implementation, is a necessary component of the flexi-quota's logic. The minister seems to hope that publicity and the fear of reputational damage will do most of the trick. Nevertheless, the proposal stipulates that both, failure to set a quota and non-compliance with the quota will be sanctioned, without specifying what type of sanction is being envisaged. ${ }^{3}$

\footnotetext{
${ }^{1}$ Cf. Langenbucher (2011a) § 4 recital 112 et seq. with accompanying footnotes.

2 Cf Langenbucher (2011b) summarizing an expertise on preliminary plans for a "flexi-quota".

${ }^{3}$ http://www.flexi-quote.de/faq-zur-flexi-quote.html
} 


\subsection{The draft bill introduced by the social democratic party}

A number of draft bills have been discussed in parliament, ${ }^{1}$ official hearings in January 2013 were held on two drafts, one of which introduced by the social democratic party, ${ }^{2}$ the other one put forward jointly by that party and the green party.

The social-democratic party's draft bill addresses listed stock corporations as well as companies which fall under the German law of mandatory employee representation. The social democratic party's draft bill encompasses supervisory boards as well as management boards. As far as supervisory boards are concerned, both, board members elected by the shareholders as well as employee representatives, fall under the proposed rule's scope.

The law is to come into force immediately and require corporations to implement a quota of $30 \%$ as regards supervisory boards and $20 \%$ for management boards. Two years later, the quota is raised to $40 \%$ for both boards. There are no exceptions to the rule provided for.

The draft bill aims at company law specific sanctions when stipulating that an appointment of members of the management board and an election of members of the supervisory board "will only be possible" if in compliance with the quota. Appointments/elections not complying with the quota are to be regarded as legally void. Hence, the members appointed/elected are not members of a board in breach of the law. Instead, they do not become board members at all. It follows that actions of the management board are, with minor variations according to the corporation's bylaws, void and cannot legally bind the corporation. The draft bill does not provide for specific remedies for third parties. As long as a compliant board has not been appointed, one will have to resort to the stock corporation act's court procedure which allows a court to appoint suitable candidates in situations where the minimum number of legally required board members is not reached.

The drafters of the bill are not too worried by the threat of the corporation not being able to act in a legally binding fashion. They point to the fact that very often actions of the supervisory board may still be legally valid if a sufficient number of members take part in the decision. This goes back to section 108 of the German stock corporation act which stipulates that a supervisory board's quorum may be defined in the corporation's bylaws. Should there be no relevant provision in the bylaws, the stock corporation act stipulates a quorum of a minimum of one half of its members being present. Let us assume a quota of $30 \%$ is introduced. The B-corporation's shareholder's general meeting votes for men only. Let us further assume a sufficient number of vacancies could have been filled in order to meet the quota requirement. The election of the "wrong" candidates is legally void (we will leave aside the complexities of figuring out who is the wrong candidate out of a number of candidates). The supervisory board may still have a quorum since $70 \%$ of its members are proper members and section 108 requires a quorum of $50 \%$ only. However, according to the draft bill a supervisory board may be non-compliant for a maximum of one year. After lapse of 12 months, the draft bill stipulates that the supervisory board loses its capacity to act in a legally binding fashion.

\footnotetext{
${ }^{1}$ Draft bill by the green party of 20.10.2010, available at Bundestags-Drucksache 17/3296; draft bill by the Land of Nordrhein-Westfalen of 25.11.2011, available at Bundesrats-Drucksache $87 / 11$; draft bill by the socialdemocratic party of 6.3.2012 available at Bundestags-Drucksache 17/8878; draft bill by the town Hamburg of 29.5.2012, available at Bundesrats-Drucksache 330/12.

${ }^{2}$ Bundestags-Drucksache $17 / 8878$.
} 


\subsection{The draft bill jointly introduced by the social democratic party and the green party}

The most recent bill was jointly introduced by the social democratic party and the green party in October of $2012 .{ }^{1}$ It advocates a significantly milder compromise, hoping to quickly introduce the bill. This rush is to be read against the background of 2013 being a so-called "super-election-year" for supervisory boards. Looking at corporations listed under the DAX 30 index alone, 77 open posts will need to be filled.

The draft bill's scope encompasses listed stock corporations or corporations which fall under the German law of mandatory employee representation. It applies to supervisory boards only and covers the entirety of the board members.

The quota introduced is to come into effect on $1^{\text {st }}$ January 2018 . It is set at $20 \%$, only on $1^{\text {st }}$ January 2023 it is to be raised to $40 \%$. Granting the considerable transition period of five years for the $20 \%$ quota to apply and another five years for it to reach $40 \%$, accounts for perceived difficulties in finding suitable candidates.

The bill includes a mechanism in order not to compromise small boards where finding candidates may prove tricky: Boards with three to six members satisfy the quota when electing one candidate of the underrepresented gender. Boards with seven or eight members fulfil the quota when comprising two such candidates; the quota of $20 \%$ applies only for boards comprising nine or more members. After 2023, requirements are to tighten. Boards with two to four members need one candidate of the underrepresented gender, boards with five to six members need two such members. Boards with seven or eight members need three "minority" members.

The proposed law stipulates a seemingly broad exception to the rule. Whenever the corporation shows that "in spite of considerable efforts" no suitable candidates could be found, the rule doesn't apply. In the bill's annotations, this rule appears to lose some of its vagueness. It is to be "interpreted very narrowly" and the drafters assess the probability of not finding suitable candidates as "extremely low". A federal agency is to decide upon acceptance of the reasons put forward by the corporation.

Sanctions are quite mild. A federal agency is to testify compliance of a corporation with the legal rule and annually publish statistics, including a "naming-and-shaming"-mechanism. The corporation is required to annually report on the composition of their supervisory board and on compliance with the legal quota. Disregarding the reporting requirement entails the possibility of a fine. The corporation loses tax privileges for remuneration paid to the entirety of a non-compliant board, if the shareholders representatives' side of the board is not in compliance with the quota requirement.

The draft bill proposes no further sanctions regarding the specifics of company law, thus avoiding the complex topics raised earlier (see above 1.3). Instead, the draft bill expressly stipulates that legal validity of a board's actions is not hindered by that board disregarding the legal quota. Similarly, the draft bill does not allow for challenging the shareholder's assembly's election of a board on the grounds that it violates the legal quota.

\footnotetext{
${ }^{1}$ Bundestags-Drucksache 17/11139, 23.10.2012.
} 


\section{ACADEMI C SCHOLARSHI P}

\section{KEY FINDI NGS}

- A vast majority of academic scholarship is opposed to an introduction of gender quotas in corporate boards.

- Arguments against gender quotas mainly stem from (i) opposition to the underlying policy, (ii) concerns about the incompatibility with constitutional or European law and (iii) pragmatic worries about adverse consequences on corporate decisionmaking.

The introduction of a gender quota in corporate boards, it seems, is disapproved not only by public opinion in Germany but also by a majority of the legal community in general and corporate law academics more specifically.

According to a recent survey, a minority of $30 \%$ of the German population regards the underrepresentation of women in "leading positions" as "unjust". ${ }^{1}$ The answer to the question "should a gender quota promote equal opportunities?" left even less room for doubt:

\section{Figure 2: "Should a gender quota promote equal opportunities?"}

\section{total population}

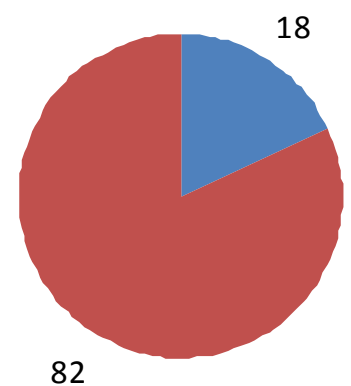

\section{female population}

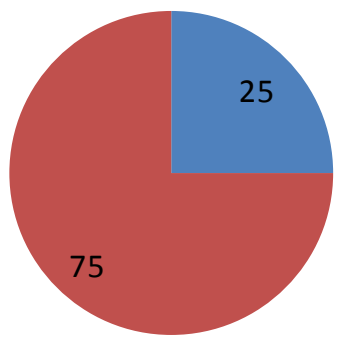

Source: Institut für Demoskopie Allensbach (2013)

The "Deutscher Juristentag" (Association of German Jurists) on its latest forum in September 2012 just as clearly voiced opposition against introducing legal quotas. ${ }^{2}$ While 71 out of 79 voters appreciate the corporate governance code's efforts to promote diversity, 58 out of 76 voters oppose a legislative quota for management boards and 62 out of 80 voters oppose a legislative quota for supervisory boards. 54 out of 80 voters oppose the "flexi-quota" advocated by the ministry for family.

\footnotetext{
${ }^{1}$ Institut für Demoskopie Allensbach (2013) p. 27.

${ }^{2}$ http://www.djt.de/fileadmin/downloads/69/121206_djt_69_beschluesse_web_rz.pdf
} 


\subsection{The policies underlying a gender quota}

Enhancing efficiency and shareholder value is often cited as the guiding policy underlying the introduction of gender quotas in business corporations. Most German academics do not subscribe to this view. If anything, they see gender quotas as a means to further fairness and social justice, loosely connected to discussions on corporate social responsibility. ${ }^{1}$ This has important implications for justifying legal action. While enhancing shareholder value provides a good reason for reforming corporate law, it is certainly much more complicated to introduce corporate law rules because of fairness concerns of social justice.

\subsection{Incompatibility with European law}

Most legal scholars view the introduction of a specific form of gender quota, namely a strict and not performed-based quota, as violating art. 8 TFEU's guarantee of equality between men and women as well as art. 23 of the Charter of Fundamental Rights of the European Union and art. 2 para. e subpara. 1, 4 of the equal treatment directive 2006/54/EC.2 Scholars point to the ECJ's decisions in Kalanke, Badeck and Marshall, where the court opposed legal rules requiring automatic promotion of women irrespective of performancebased criteria. It is claimed that the introduction of a gender quota for boards falls into the category of strict, not performance based quotas. This argument refers to fix quotas (e.g. $40 \%$ ) which need to be fulfilled even if we assume a case where it was undisputed that the available female candidates are less qualified than their male competitors. Hence, any quota to be introduced will need to take into account the court's jurisprudence on this form of "reverse discrimination". In the past, the ECJ accepted quotas including the requirement of female candidates being as qualified as male candidates (merit-based appointment) as well as a rule granting exceptions for certain cases of impossibility of finding a female candidate. It might be noted, however, that the ECJ's jurisprudence so far concerns cases of employment. Few scholars have discussed to what extent this line of reasoning can be applied to the membership of a board which seems to display quite a number of features distinguishing it from employment situations. ${ }^{3}$

\subsection{Incompatibility with German constitutional law}

An overwhelming majority of German corporate law scholars oppose gender quotas for constitutional reasons. Interestingly, there is much less opposition from constitutional law scholars on that same point. There are two main lines of reasoning for this opposition. The first one refers to the concerns of reverse discrimination we have just outlined with equal protection of men and women granted by Art. 3 of the German constitution. The second line of reasoning is concerned with Art. 14's protection of property rights.

According to Art. 14 of the German constitution shareholders are protected as owners of the corporation. Any rule limiting their rights flowing from this property position fall under scrutiny by the Constitutional Court. The right to elect the board, it is argued, constitutes a prime shareholder right. Hence, a rule limiting the shareholder's freedom to choose whoever they consider fit possibly violates the constitution. Of course, there are a number

\footnotetext{
1 Fleischer (2012; Habersack (2012) p. 26; more openness towards gender concerns: Bayer (2013) p. 7; Möllers/Hailer (2012) p. 844, 847 et seq.

${ }^{2}$ Bachmann (2011a) p. 1131.

${ }^{3}$ Bachmann (2011a) p. 1135 ; Langenbucher (2012) p. 322;
} 
of legal rules which sensibly limit this freedom - rules requiring the required mental capacity, a minimum age or the absence of criminal offences provide good examples. Where do we draw the line? The German Constitutional Court acknowledges the high complexity of property rights being defined by the legislator ("what counts as a property right?") and that same legislator being bound by the constitution's guarantee of property ("does a law redefining a property right violate the constitution?"). The test it applies is a proportionality test. Firstly, the law's policy will be scrutinized: is the goal the legislator aims at when introducing the law a proper one? As to gender quotas, the legislator may point to both, enhancing shareholder value as well as fairness concerns of equality between men and women. Secondly, the legal instrument chosen will be tested against constitutional principles. The rule chosen by the legislator will need to qualify as apt, necessary and proportionate.

The Constitutional Court's most important precedent concerns the establishment of codetermination on corporate boards in the 70s. ${ }^{1}$ The Constitutional Court accepted codetermination, pointing to the large discretion the legislator enjoys as well as the proportionality test being met. One argument in favour of the constitutionality of this rule was the fact that board members elected by the shareholders are granted the deciding vote. Consequently, whenever the "owner's side" of a board votes unanimously, the "employee side" cannot overturn that vote.

Some corporate law scholars argue that (i) the legislator's policy cannot be described as enhancing shareholder value but solely as promoting social justice and (ii) a rule promoting social justice may never justify reforming corporate law. ${ }^{2}$ Others point to a "cumulation effect": ${ }^{3}$ The shareholder's freedom to elect their preferred candidate is limited not only by co-determination but also by EU law requiring a financial expert. Piling a gender quota on top of those restrictions, it is argued, would violate the constitution's guarantee of property rights.

It seems that the majority of constitutional law scholars do not share their corporate law colleague's skepticism. ${ }^{4}$ They point to the German constitutional court's decision upholding co-determination and claim that a gender quota might well pass the proportionality test provided that the rule accounts for fears of reverse discrimination.

\subsection{Lack of competence for the European legislator}

Adding to constitutional concerns, most German corporate law scholars claim that there is no competence for the European legislator to pass a directive introducing gender quotas. ${ }^{5}$ This is based on general views on subsidiarity as well as on the more specific denial that art. 157 para. 3 TFEU or art. 50 para. 2 lit. g TFEU allow for a directive of this type. The latter requires a "safeguard [...] for the protection of the interests of members and others". Gender quotas are viewed as a fairness measure of social justice, not providing competence for the European legislator to pass a company law directive. The former picked by the Commission - applies to employment situations exclusively. It is doubtful

\footnotetext{
${ }^{1}$ BVerfGE 50, 290.

${ }^{2}$ Hoffmann-Becking (2011) p. 1173

${ }^{3}$ Habersack (2012) p. 29 et seq. ; Hirte (2011) p. 524 et seq.

${ }^{4}$ Papier/Heidebach (2011) p. 324.

5 Bachmann (2011a) p. 1135 ; Bachmann (2011b) p. 1304; Basedow (2013) Fleischer (2012) p. 164; Koch (2011) p. 833.
} 
whether board members, even more so if supervisory board members are concerned, may be regarded as "employees" in that sense. ${ }^{1}$

\subsection{Adverse consequences on corporate business}

While most corporate law scholars acknowledge the desirability of more female leadership in principle, they blame traditional role expectations, unwillingness of women to sacrifice family life to career concerns and insufficient childcare. ${ }^{2}$ Against this background, rules on gender quotas in corporate boards are viewed as taking private companies hostage for a goal which is if not exclusively, at least primarily a concern of social fairness and fairness. ${ }^{3}$ Especially as regards management board seats, the generally accepted view seems to be that there are currently not enough qualified women available. ${ }^{4}$

\section{CONCLUDING REMARK}

It might have become apparent that the introduction of fixed quotas, even in the watereddown version introduced by the social-democratic and the green party, meets considerable opposition in Germany. This is true for corporate law scholars as well as for public opinion.

Against this background, flexible quotas seem a promising solution to accommodate both, concerns about shareholder's rights and policies of enhancing gender balance on corporate boards. ${ }^{5}$ I have advocated elsewhere the broader concept of a "declaration of strategy". ${ }^{6}$ It would require corporations to report on their strategy for board composition, on their current status quo and on the time-line they set for achieving their reported "ideal" board composition. Such declaration is not limited to gender but might include independence, professional qualification and the like.

Considering reputational effects of a declaration of this type, one might assume that as to sanctions, disclosure should suffice and eliminate the need for the more drastic measures of annihilating elections/appointments of corporate board members.

\footnotetext{
1 Basedow (2013) p. 42.

${ }^{2}$ Habersack (2012) p. 28.

${ }^{3}$ Habersack (2012) p. 28; Hopt (2012) p. 619.

${ }^{4}$ Habersack (2012) p. 34.

${ }^{5}$ Advocating « flexible quotas » for supervisory boards Bayer (2013) p. 9.

${ }^{6}$ Langenbucher (2012) p. 26 et seq.
} 


\section{REFERENCES}

- Bachmann G. (2011a), ZIP 2011, 1131.

- Bachmann G. (2011b), WM 2011, 1301.

- Basedow J. (2013), EuZW 2013, 41.

- Bayer W. (2013), NZG 2013, 1.

- Entscheidungen des Bundesverfassungsgerichts

- Fleischer H. (2012), ZGR 2012, 160.

- Habersack M. (2012), Gutachten für den 69. DJT.

- Hirte H. (2011), Der Konzern 2011, 519.

- Hoffmann-Becking M. (2011), ZIP 2011, 1173.

- Hopt K. J. (2012), NZG 2012, 619.

- Institut für Demoskopie Allensbach (2013), Was ist gerecht? Gerechtigkeitsbegriff und wahrnehmung der Bürger, 15.2.2013.

- Koch J. (2011), ZHR 175 (2011) 827.

- Langenbucher K. (2011a), Aktien- und Kapitalmarktrecht, Munich: 2011.

- Langenbucher K. (2011b), JZ 2011, 1038.

- Langenbucher K. (2012), ZGR 2012, 314.

- Möllers T./Hailer S., (2012) JZ 2012, 841.

- Papier H.J./Heidebach M., (2011), ZGR 2011, 305. 